\title{
Analysis of Supplier Rubber Dumper XP500-R Selection as a Tool for Safety Unit Using Analytical Hierarchy Process Method (AHP) at PT ABC
}

\author{
Irfan Muhamad Ramadon, Erry Rimawan, Rini Kristianti, Suryadi \\ Bachelor of Industrial Engineering, Mercu Buana University Jakarta, Indonesia
}

\begin{abstract}
The development of a nation is inseparable from the factors / roles of industry both in services and manufacturing. This is because of manufacturing and service industries are very profitable fields by various parties. The problem at $\mathrm{PT} A \mathrm{ABC}$ related to the procurement sector is that there are no methods for making decisions when there are many criteria and many decision makers. This affects when PT. ABC wants to buy a Rubber Dumper XP500-R as a safety unit, based on this problem the most appropriate method is Analytical Hierarchy Process. AHP method applied by the Expert Choice (EC) software can help choose the right supplier. AHP is used because it can calculate priority assesments for many criteria and many decision makers. The results of this priority assesments are CV Rafindo Raya (0.36570) as the first rank followed by CV Rekatama Tehnik $(\mathbf{0 . 2 3 3 2 0})$ as second, PT Dharma Geliat Sejahtera as rthird (0.22170), and the last is PT Emka Jaya Mandiri $(0,18002)$.
\end{abstract}

Keywords:- Decision Making, Crtiteria, AHP, Expert Choice, Supplier.

\section{INTRODUCTION}

A company must be able to maintain consistency so that it is always in its best condition, because more and more strong competitors are ready to always make optimal productivity. If a company fails to maintain consistency, the company will soon be defeated. In achieving the above objectives, a manufacturing company really needs a variety of things to support it. Companies must have an evaluation or improvement system to make their products superior in the eyes of customers compared to similar competitor products, one way is to make improvements.

PT. ABC is one of the companies producing fourwheeled units for auxiliary vehicles on plantations, especially oil palm plantations in Indonesia. In addition, one of the core values of the company is customer focus, which means always looking for opportunities to deliver more than customers expect through the best efforts and continuous innovation in all fields. Therefore, making Rubber Dumper is a form of improvement made by the company as a safety unit at the request of the customer, so that when the driver drives the unit and collisions occur at the front and rear of the vehicle, it is expected to minimize damage to the unit and the driver can feel safe and comfortable.

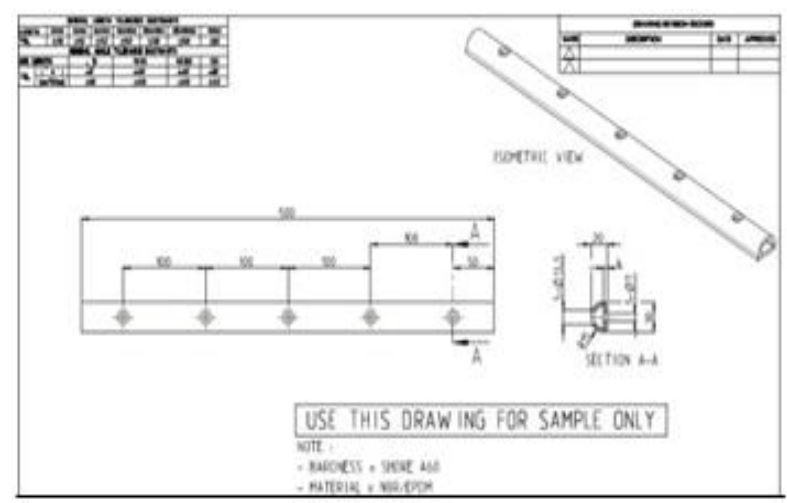

Fig 1:- Technical Drawing of Rubber Dumper

Following the Customer Request and Claim XP500-R form at $\mathrm{PT}$. ABC to request the addition of rubber dumper as a basis for the procurement of these parts, which was updated in February 2020:

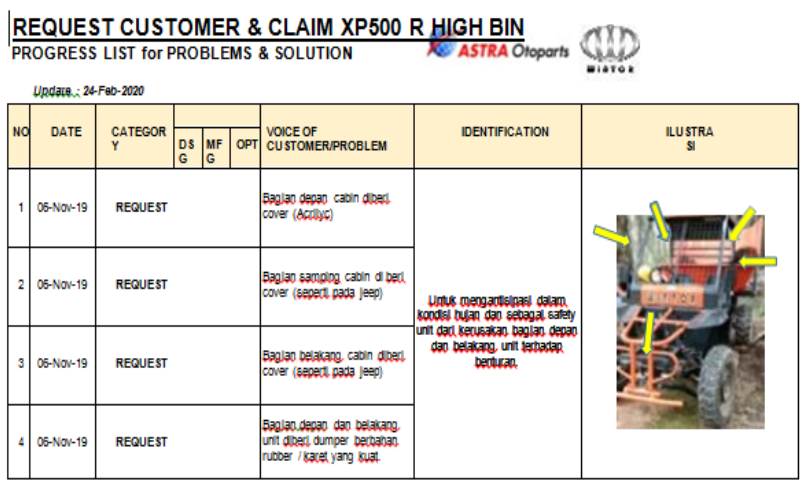

Fig 2:- Form Request and Claim Customer

The high demand for XP500-R wintor units in the final months of 2019 of the palm oil plantation industry in Indonesia, makes the company always do research and development of their products through the company's RND division. By thinking about the cost of production, to carry out development requires several kinds of things, including the price of raw materials that are low but have good quality. In addition, because customer satisfaction and needs are prioritized by the company, by considering the safety and maintenance of the unit, an experiment is made by adding a safety unit such as a Rubber Dumper mounted on the front and rear of the body unit. 


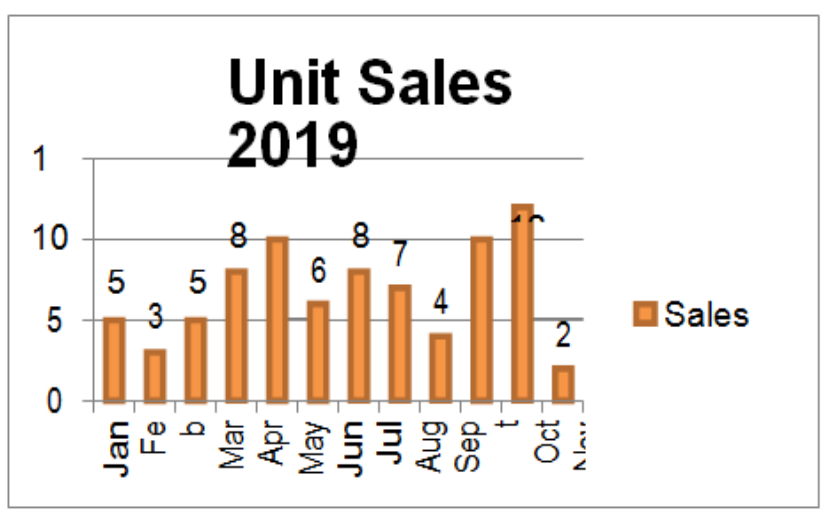

Fig 3:- Unit Sales 2019 of XP500-R

To fulfill the procurement, every company has a division to conduct supplier selection by using a method that supports the achievement of optimal desires. The method that is often used is a satisfaction support system, this is useful to facilitate decision making in finding the best supplier selection. Decision making is the process of choosing an alternative choice using methods / methods that are very efficient with the existing situation. (Reason, 2010) Decision making often occurs by individuals and groups. A person or a team that is made as a decision maker must use good and appropriate methods, so that the selected results are the best results and very accurate results.

However, there are many weaknesses in decision making. One disadvantage is that they often use intuition or experience in choosing a choice. There is no further review or more analytical study. In conducting the study, a person who is directly involved with the problem is needed. One method that is often used to make decisions is the Analytical Hierarchy Process (AHP) method. Strengths AHP has the ability to solve multi-objective and multi-criteria problems based on comparing the preferences of each element in the hierarchy. So, this model is a comprehensive decision making model. (Saaty, 1993).

\section{LITERATURE REVIEW}

\section{A. Decision Making}

Decisions are the result of solving a problem that must be dealt with firmly. In the Large Dictionary of Decision Making Science (Decision Making) is defined as the selection of decisions or policies based on certain criteria. This process includes two or more alternatives because if there is only one alternative there will not be one decision to be taken. According to Reason (2010) decision making can be considered as an outcome or output from mental or cognitive processes that lead to the selection of an action pathway among several available alternatives. Every decision making process always results in one final choice.

According to Suharman (2005), decision making is the process of choosing or determining various possibilities among uncertain situations. Kotler (2009), explains the decision making process as follows:

$>$ Identification of Problems

$>$ Data Collection and Analysis
Making Alternatives - Policy Alternatives

Selection of One of the Best Alternatives

$>$ Decision Implementation

$>$ Monitoring and Evaluation of Decisions

\section{B. Nominal Group Technique (NGT)}

Nominal Group Technique (NGT) is a structured method used to dig deeper into the contribution of each participant. (Tague, 2004). NGT is the process of finding a solution to a problem which includes the process of identification, finding common solutions, and decision making. NGT is one of the quality tools that is useful in making the best decisions. In quality management, this method can be used for various things, from finding solutions to problems, to choosing new product development ideas. So, later the priority of these problems will be followed up with an intervention plan. According to Supriyanto and Nyoman (2007) the steps in implementing NGT are as follows:

$>$ Introduction

$>$ Generating Ideas

$>$ Sharing \& Recording Ideas

$>$ Discussing Ideas Voting \& Rangking Ideas

\section{Expert Choice (EC)}

Expert Choice is a software that supports collaborative decisions and hardware systems that facilitate group decision making that is more efficient, analytical, and justified. Enables real-time interaction from the management team to reach consensus on decisions. (Putu Gede, 2011).

\section{Analytical Hierarchy Process (AHP)}

Analytical Hierarchy Process (AHP) method developed by Thomas L. Saaty is one of the methods that can be used in decision making systems by taking into account factors of perception, preference, experience and intuition. AHP combines personal judgments and values in a logical way.

Analytical Hierarchy Process (AHP) can solve complex multi-criteria problems into a hierarchy. According to Saaty (1993), hierarchy is defined as a representation of a complex problem in a multi-level structure where the first level is the goal, followed by the level of factors, criteria, sub-criteria, and so on down to the last level of alternatives.

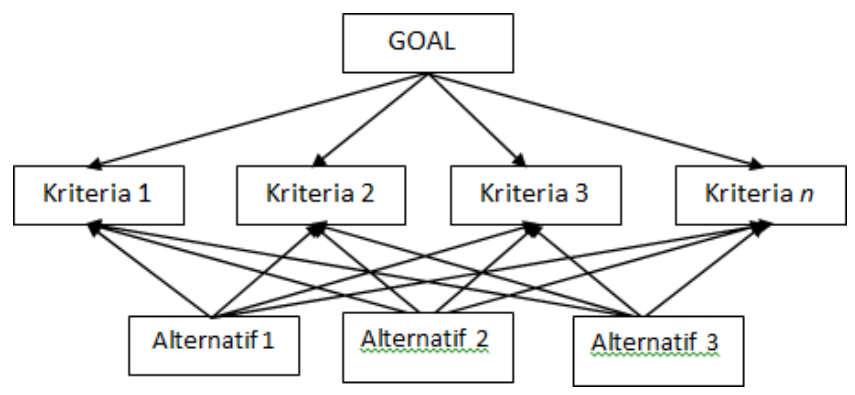

Fig 4:- AHP Hierarchy Structure 
To get a rational decision using AHP, it needs to do several stages. Broadly speaking, the stages in AHP are modeled by the following figure:

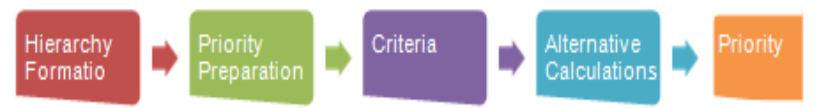

Fig 5:- Flow Process of AHP's Stages

\section{E. Supplier Selection}

Selection of suppliers usually consider the quality of the product, service / service and on time delivery are important, although there are several other factors that must be considered. The main factors considered by a company when choosing a supplier are: (William J Stevenson, 2002: 701)

\section{$>$ Price}

This factor is usually the main factor, whether there is a discount offer, even though it is sometimes not the most important thing.

\section{Quality}

A company might spend more on the quality of goods.

\section{Service}

Special service can sometimes be important in selecting suppliers. Replacement of damaged goods, instructions on how to use, repair equipment and similar services, can be key in choosing one supplier over another.

\section{Location}

The location of the supplier can have an influence on delivery times, transportation costs, and response times when there are sudden orders or emergency services. Purchasing in the local / local area can foster goodwill (good influence) in a relationship and can help the economy of the surrounding area.

\section{Supplier inventory policy}

If a supplier can maintain its inventory policy and maintain its spare parts, this can help in the case of sudden raw material requirements.

\section{Flexibility}

Good intentions and the ability of suppliers to respond to changes in demand and meet changes in order design can be important factors in supplier selection.

\section{F. Supplier Selection Criteria}

According to Gary W Dickson (1966) in I Nyoman Pujawan and Mahendrawathi (2010: 155), stated twentyone criteria for supplier selection and evaluation can be seen in table 1 . With many criteria that exist in the selection of suppliers, but the decision in determining the criteria to be used in a company are determined by the company itself. The company will choose several criteria, the choice of criteria usually depends on the items of raw materials supplied to the company.
ISSN No:-2456-2165

\begin{tabular}{|l|l|l|l|}
\hline No & \multicolumn{1}{|c|}{ Kriteria } & $\mathrm{N}_{0}$ & \multicolumn{1}{c|}{ Kriteria } \\
\hline 1 & Kualitas / Quality & 12 & Management and Organization \\
\hline 2 & Delivery & 13 & Operating Controls \\
\hline 3 & Performance History & 14 & Attitudes \\
\hline 4 & Warranties and Clain Policies & 15 & Impressiom \\
\hline 5 & Price / Cost & 16 & Packaging Ability \\
\hline 6 & Technical Capability & 17 & Labor Relation Records \\
\hline 7 & Financial Position & 18 & Geographical Location \\
\hline 8 & Prosedural Compliance & 19 & Amount of Past Business \\
\hline 9 & Communication System & 20 & Training Aids \\
\hline 10 & Reputiation and Position in Industry & 21 & Reciprocal Arrangements \\
\hline 11 & Desire for Business & & \\
\hline
\end{tabular}

Table 1:- Supplier Selection / Evaluation Criteria

\section{METHODOLOGY}

\section{A. Data Collection}

The data collection methods used to obtain data in writing this thesis are:

The researcher uses several data collection techniques as follows:

\section{> Observation}

Data collection by directly observing the location of research sites.

\section{Interview}

Interview is a data collection technique that is done through face-to-face and question and answer between data collectors and researchers towards the sources or data sources.

\section{Questionnaire}

Questionnaire is a data collection technique that is done through questions posed by relevant resource persons in accordance with the analysis of the requirements needed by the author.

\section{$>$ Documentation}

Data collection by recording company data in accordance with the issues studied.

\section{B. Expert Respondents}

Respondents of this study are respondents who are considered experts in terms of supplier assessment in accordance with company needs for procurement of Rubber Dumper unit XP500-R. What is meant by expert respondents here are respondents who have experience and their field of work involved for years in the process of assessing the performance of an external supplier / provider to meet the needs of the company.

\begin{tabular}{|c|l|l|l|}
\hline No & \multicolumn{1}{|c|}{ Name } & \multicolumn{1}{c|}{ Position } & \multicolumn{1}{c|}{ Experience } \\
\hline 1 & Benny Herwanto & Dept. Head Procurement & 25 Tahun \\
\hline 2 & Junior Dharmawan & Section Head Purchasing & 13 Tahun \\
\hline 3 & M. Julydharta .S & Section Head Vendor Development & 9 Tahun \\
\hline 4 & Suherman .M & Section Head GA \& Logistic & 15 Tahun \\
\hline
\end{tabular}

Table 2:-Respondents 


\section{Selection Criteria for Supplier Rubber Dumper XP500-R}

The following are the criteria chosen by the author based on the results of the Nominal Group Technique (NGT) that has been carried out to determine the selection of Rubber Dumper suppliers at PT. A B C. Criteria that have been collected are secondary data from the company and the results of several references. These criteria can be seen in Table 3 below:

\begin{tabular}{|c|l|l|}
\hline No & \multicolumn{1}{|c|}{ Kriteria } & \multicolumn{1}{c|}{ Referensi } \\
\hline 1 & Kualitas / Qvalio & Wulliam J, 2002 \\
\hline 2 & Kuantitas/Quantity & William J, 2002 \\
\hline 3 & Harga / Cost & Wulliam J, 2002 \\
\hline 4 & Pengrman / Deliveny & Dickson, 1996 \\
\hline 5 & Pembayaran/Poyment & Dickson, 1996 \\
\hline 6 & Pelayanan/Service & Willam J, 2002 \\
\hline
\end{tabular}

Table 3:- 6 of Research Criteria

\section{Determination of Supplier Alternative}

Based on the criteria regarding the selection of suppliers of Rubber Dumper XP500-R above, 4 alternatives have been determined after going through the bid request / quotation process via electronic mail and also the results of NGTs that have been made, here the four alternatives that will be selected in determining the supplier of Rubber Dumper XP500-R are:

$>$ CV. Rafindo Raya

$>$ CV. Technical Rekatama

$>$ PT. Dharma Stretching Prosperous

$>$ PT. Emka Jaya Mandiri

\section{E. Framework}

This research process the data quantitatively, the data obtained in the study will be processed and analyzed so that it can provide a clear work system. The research stages can be seen in Figure 6.

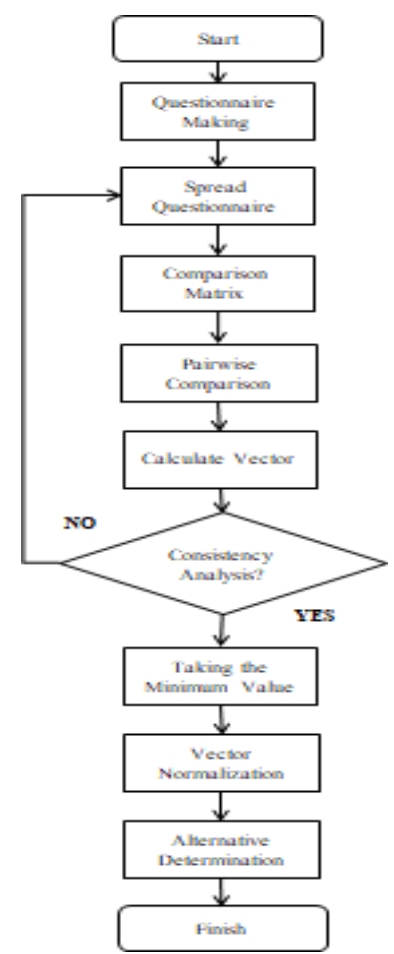

Fig 6:-Research Stages

\section{RESULTS AND DISCUSSION}

Criteria and alternative assessment methods for selecting the XP500-R rubber dumper supplier using the AHP method previously conducted by Nominal Group Technique (NGT), interviewing the company, and conducting search observations through a journal study (Reference). In the criteria in this study related to the selection of suppliers and alternatives in PT. $\mathrm{ABC}$ is as follows: From table 2 then made in the form of a supplier selection criteria hierarchy. Following is the hierarchy of supplier selection criteria:

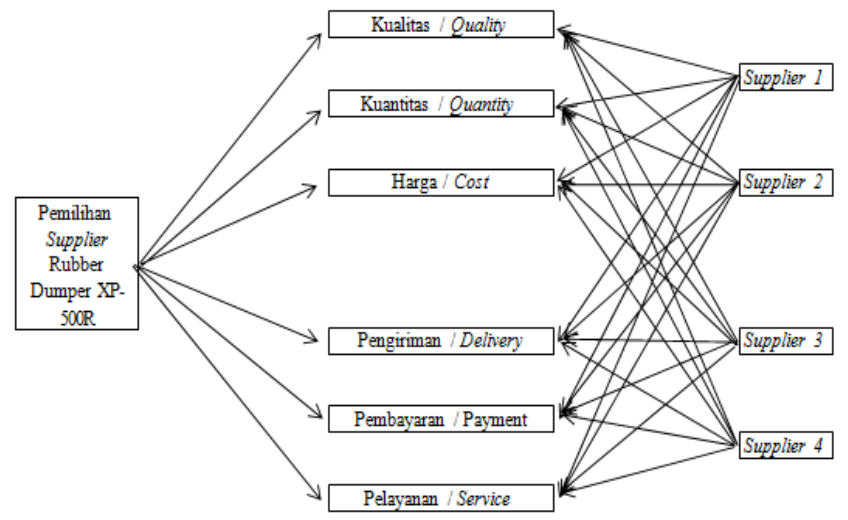

Fig 7:- Hierarchy of Supplier Selection

After going through the process of distributing and filling out the questionnaire to expert respondents. Following are the results of calculations using AHP for the calculation of the assessment criteria of quality, quantity, cost, delivery, payment, and service, followed by the calculation of alternative assessments of each criterion. Then the calculation is continued using Expert Choice. On this occasion we will use an example of a questionnaire from respondent 1 .

\begin{tabular}{|l|c|c|c|c|c|c|}
\hline Kriteria & Quality & Quantity & Cost & Delivery & Payment & Service \\
\hline Quality & 1,00 & 3,00 & 1,00 & 0,50 & 4,00 & 4,00 \\
\hline Quantity & 0,33 & 1,00 & 0,20 & 1,00 & 3,00 & 1,00 \\
\hline Cost & 1,00 & 5,00 & 1,00 & 2,00 & 3,00 & 3,00 \\
\hline Delivery & 2,00 & 1,00 & 0,50 & 1,00 & 4,00 & 2,00 \\
\hline Payment & 0,25 & 0,33 & 0,33 & 0,25 & 1,00 & 2,00 \\
\hline Service & 0,25 & 1,00 & 0,33 & 0,50 & 0,50 & 1,00 \\
\hline
\end{tabular}

Table 4:-Results of Respondents Criteria Questionnaire 1

Furthermore, data processing is carried out in three stages, namely:

$>$ Calculate the consistency ratio of each respondent to see whether it is consistent or not.

$>$ Combining respondents' ratings of the relative importance of each criterion. Group assessments in AHP can be combined into one assessment, namely through geometric averages of the respondents' ratings.

$>$ Calculate the weight that is a priority for each criterion and the ratio of its consistency. 
The pairwise comparisons in this matrix are the result of calculating the geometric mean of the respondents' ratings. With the final results of the calculation of each criterion as follows:

Normalisasi / Nilai Eigen

\begin{tabular}{|l|c|c|c|c|c|c|c|c|c|c|}
\hline Kriteria & Quality & Quantity & Cost & Delivery & Payment & Service & Jumlah & Prioritas & & \\
\hline Quality & 0,21 & 0,26 & 0,30 & 0,10 & 0,26 & 0,31 & 1,43 & 0,24 & 1,57 & 6,57 \\
\hline Quantity & 0,07 & 0,09 & 0,06 & 0,19 & 0,19 & 0,08 & 0,68 & 0,11 & 0,76 & 6,70 \\
\hline Cost & 0,21 & 0,44 & 0,30 & 0,38 & 0,19 & 0,23 & 1,75 & 0,29 & 1,96 & 6,71 \\
\hline Delivery & 0,41 & 0,09 & 0,15 & 0,19 & 0,26 & 0,15 & 1,25 & 0,21 & 1,39 & 6,65 \\
\hline Payment & 0,05 & 0,03 & 0,10 & 0,05 & 0,06 & 0,15 & 0,45 & 0,07 & 0,47 & 6,31 \\
\hline Service & 0,05 & 0,09 & 0,10 & 0,10 & 0,03 & 0,08 & 0,44 & 0,07 & 0,49 & 6,57 \\
\hline
\end{tabular}

Table 5:- Final Results of each criterion

After that, we calculate the consistency ratio using formula 1.1, with the following results:

$\mathrm{CI}=(\lambda \max -\mathrm{n}) /(\mathrm{n}-1)$

where the Maximum Eigenvalue is:

$\lambda$ maks $==$

6,58

next, with the number of elements $\mathrm{n}=6$ so, the Consensus Index $(\mathrm{CI})$ is:

$$
=0.12
$$

Next, calculate the Consistency Ratio (CR) using formula 1.2, the results are as follows:

with the number of criteria (n) of 6 , according to table 1.6 of the Random Index, the RI value used is 1.24 , so the results are as follows:

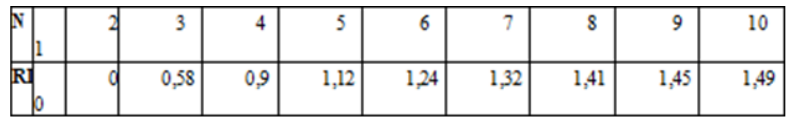

Table 6: Random Index Number

$-=0.09$

Because, $\mathrm{CR}<0.1$ Then the calculation has been done consistently.

After getting the consistency ratio, the next is to calculate the weight for all by doing geometric averages to the results of the fourth questionnaire respondents then calculated geometrically. With the following formula 1.3 and results:

$$
G M=\sqrt[n]{\left(X_{1}\right)\left(X_{2}\right) \ldots . .\left(X_{n}\right)}
$$

Dimana

$$
\begin{aligned}
\mathrm{GM} & =\text { Geometric Mean } \\
\mathrm{X} 1 & =\text { Pakar ke-1 } \\
\mathrm{X} 2 & =\text { Pakar ke-2 } \\
\mathrm{Xn} & =\text { Pakar ke- } \mathrm{n}
\end{aligned}
$$

\begin{tabular}{|c|c|c|c|c|c|c|}
\hline Krtaria & Qualiny & Quatity & Cout & Delivery & Payect & Service \\
\hline Qualiy & 1,00 & 2.59 & 1,32 & 1,46 & 2.63 & 1,32 \\
\hline Quasty & 0,39 & 1,00 & 0.56 & 1.32 & 1.57 & 0,80 \\
\hline Cost & 0,76 & 1,78 & 1,00 & 221 & 2,06 & 1,19 \\
\hline Delinery & 0,69 & 0,76 & 0,45 & 1.00 & 251 & 1,07 \\
\hline Pryment & 0,38 & 0,64 & 0,49 & 0,40 & 1.00 & 0.73 \\
\hline Service & 0.38 & 1.28 & 0.54 & 0.93 & 137 & 1.00 \\
\hline
\end{tabular}

Where's :

$\mathrm{GM}=$ Geometric Mean, $\mathrm{X} 1=$ Respondent $1, \mathrm{X} 2=$ Respondent 2 , X3 = Respondent 3, X4 = Respondent 4

$$
\mathrm{GM}=\sqrt{=0,39}
$$

Table 7:- Result of Geometric Criteria

Next is to calculate the value of the geometric results as above the previous calculation, with the following results :

\begin{tabular}{|l|r|}
\hline Criteria & Priority \\
\hline Quality & 0,26 \\
\hline Quantity & 0,13 \\
\hline Cost & 0,22 \\
\hline Delivery & 0,15 \\
\hline Payment & 0,09 \\
\hline Service & 0,14 \\
\hline
\end{tabular}

\section{Result of Criteria Priority}

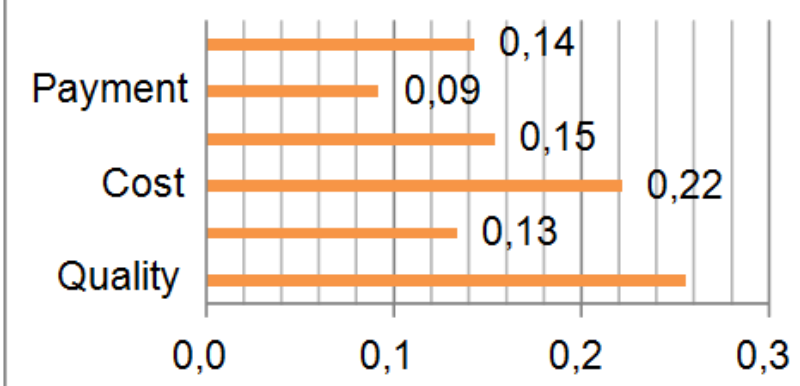

Fig 8:- Final Result of Criteria Priority

Next, calculate the comparison between the main and alternative criteria. Using the same calculations as above, here are the results of the geometric assessment for supplier selection:

\begin{tabular}{|l|c|}
\hline Alternatif & Bobot Prioritas \\
\hline CV RAFINDO & 0,37 \\
\hline CV REKATAMA & 0,23 \\
\hline PT DGS & 0,22 \\
\hline PT EMM & 0,18 \\
\hline
\end{tabular}




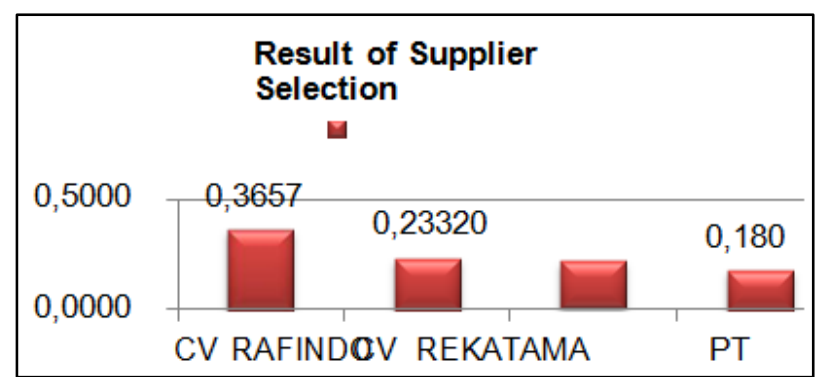

Fig 9:- Final Results of Supplier Selection

Next, the calculation is using the Expert Choice, Following the Comparison Matrix Results and the Rastio of the Alternative Geometric Consistency with the Main Criteria Using Expert Choice 11, the results is bellows :

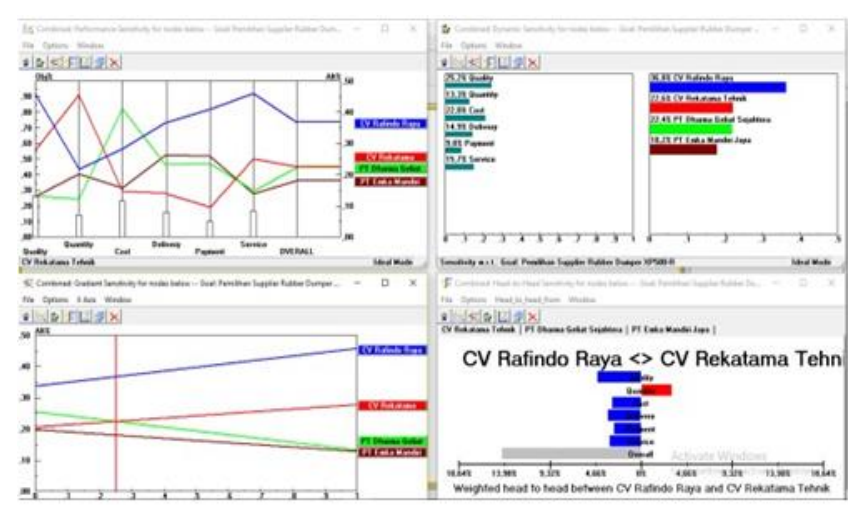

Fig 10:-Four Graph of Results Expert Choice

Based on the Performance Analysis results of calculations using expert choice 11 for the four respondents or it can be said the results of the combined calculation above, it can be seen that the highest evaluation criteria are Quality, followed by Cost, third Service, fourth Delivery, fifth there is Quantity and finally Payment. Furthermore, an alternative assessment for the four respondents, it can be seen that the assessment with the highest criteria is the $C V$. Rafindo, the second CV Rekatama Tehnik the third is PT Dharma Geliat Sejahtera, and the last is PT Emka Jaya Mandiri.

The criterion gets the highest score because it has a high score from the respondent compared to other criteria. So that when done the assessment criteria get the highest value compared to other criteria. In line with the results from Dynamic charts, Weighted Height to Height charts, and Gradient charts.

\section{CONCLUSION}

From the results of the above processing can be made a table to determine the selection of the right Supplier Rubber Dumper XP500-R, Here is a table 8 to determine the selection of the right Supplier:
ISSN No:-2456-2165

\begin{tabular}{|c|c|c|c|c|}
\hline No & Kriteria & Bobot & Alternatif & Bobot Prioritas \\
\hline \multirow[t]{4}{*}{1} & Quality & 0,26 & CV Bafiode Raya & 0,44 \\
\hline & & & CV Bekatama Tehoik & 0,29 \\
\hline & & & PT Dharma Geliat Sejahtera & 0,14 \\
\hline & & & PT Enka Jaya Mandici & 0,13 \\
\hline \multirow[t]{4}{*}{2} & Quantity & 0,13 & CV Rafinde Raya & 0,22 \\
\hline & & & CV Bekatama Tehoik & 0,45 \\
\hline & & & PT Dharma Geliat Sejahtera & 0,13 \\
\hline & & & PT Enka Jaya Mandici & 0,20 \\
\hline \multirow[t]{4}{*}{3} & Cost & 0,22 & CV Bafiode Raya & 0,29 \\
\hline & & & CV Rekatama Tehoik & 0,15 \\
\hline & & & PT Dharma Geliat Sejahtera & 0,41 \\
\hline & & & PT Enka Jaya Mandici & 0,16 \\
\hline \multirow[t]{4}{*}{4} & Delivery & 0,15 & CV Bafiode Raya & 0,37 \\
\hline & & & CV Rekatama Tehoik & 0,14 \\
\hline & & & PT Dharma Geliat Se jahtera & 0,23 \\
\hline & & & PT Enka Jaya Mandici & 0,26 \\
\hline \multirow[t]{4}{*}{5} & Payment & 0,09 & CV Bafiede Raya & 0,41 \\
\hline & & & CV Rekatama Tehoik & 0,10 \\
\hline & & & PT Dharma Geliat Sejahtera & 0,24 \\
\hline & & & PT Enka Jaya Mandici & 0,26 \\
\hline \multirow[t]{4}{*}{6} & Service & 0,14 & CV Rafiode Raya & 0,46 \\
\hline & & & CV Bekatama Tehoik & 0,25 \\
\hline & & & PT Dharma Geliat Sejahtera & 0,15 \\
\hline & & & PT Emka Jaya Mandici & 0,14 \\
\hline
\end{tabular}

Table 8:-Results value of selection the right Supplier Rubber Dumper XP500-R

Based on the results obtained can be concluded as follows :

$>$ Based on the table 8 , it can be seen that the highest evaluation criteria are Quality with a value of 0.26 , Cost with a value of 0.22 , Delivery with a value of 0.15 , Service with a value of 0.14 , Quantity with a value of 0.13 and Payment with a value of 0,09 . The criterion gets the highest score because it has a high score from the respondent compared to other criteria. So that when the assessment is made the criteria get the highest value compared to the other criteria.

$>$ The results of the alternatives obtained for the selection of suppliers Rubber Dumper XP500-R with the Analytical Hierarchy Process (AHP) method are as follows:

- CV Rafindo Raya

- CV Rekatama Tehnik

- PT Dharma Geliat Sejahtera

- PT Emka Mandiri Jaya

From these results it can be seen that, the alternative selection of Supplier Rubber Dumper XP500-R obtained is CV Rafindo Raya.

\section{REFERENCES}

[1]. Thill, J. C. (Ed.). (2019). Spatial multicriteria decision making and analysis: a geographic information sciences approach. Routledge.

[2]. Amor, S. B., de Almeida, A. T., de Miranda, J. L., \& Aktas, E. (Eds.). (2019). Advanced Studies in MultiCriteria Decision Making. CRC Press.

[3]. Heriwan, P., Kholil, M., \& Gadisa, A. 2015. Analisa Pengambilan Keputusan Penentuan Cairan Antiseptik Tangan Yang Terbaik dengan Metode Analytical Hierarchy Process (AHP). Jurnal PASTI Volume IX No 2, $203-219$ 
[4]. Kholil, M., \& Octaviani, R. (2013). Application of AHP Method for selecting the best strategy to reduce environmental demage caused by non metallic mining Case study in Gunungkidul Regency, Yogakarta, Indonesia.

[5]. Hariwan, P., Kholil, M., \& Gadissa, A. A. N. (2015). Analisa Pengambilan Keputusan pada Penentuan Cairan Antiseptik Tangan yang Terbaik dengan Metode Analytical Hierarchy Process (Ahp)(Studi Kasus: Laboratorium Mikrobiologi PT Sandoz Indonesia). Penelitian Dan Aplikasi Sistem Dan Teknik Industri, 9(2), 182845.

[6. Rimawan, E., \& Saputra, Y. Supplier Selection Criteria Using the Analytical Network Process Method.

[7]. Song, J. S., Shin, S. S., \& Lee, S. H. (2017). A Study on the Application of EXPERT-CHOICE Technique for Selection of Optimal Decontamination Technology for Nuclear Power Plant of Decommissioning. Journal of Nuclear Fuel Cycle and Waste Technology (JNFCWT), 15(3), 231- 237.

[8]. Erdogan, S. A., Šaparauskas, J., \& Turskis, Z. (2017). Decision making in construction management: AHP and expert choice approach. Procedia engineering, 172, 270-276. 